\title{
HUBUNGAN PENGETAHUAN DAN SIKAP PETUGAS PENJAMAH MAKANAN DENGAN PRAKTEK PENGELOLAAN MAKANAN
}

\author{
Lilis Banowati*, Euis Siti Kurniasari**
}

\begin{abstract}
ABSTRAK
Penyelenggaraan makanan bermutu di rumah sakit tidak terlepas dari tenaga penjamah, tenaga penjamah adalah seorang tenaga yang menjamah makanan dan terlibat langsung dalam menyiapkan, mengolah, mengangkut maupun menyajikan makanan. Berdasarkan wawancara terhadap 10 pegawai mengatakan bahwa $65 \%$ kurang memahami tentang penyelenggaraan makanan yang baik dan benar. Tujuan penelitian ini untuk mengetahui hubungan pengetahuan dan sikap petugas penjamah makanan dengan praktek pengelolaan makanan di Instalasi Gizi RSUD Cideres Kabupaten Majalengka Tahun 2014. Jenis penelitian adalah penelitian deskriptif korelatif dengan menggunakan pendekatan cross sectional. Jumlah sampel sebanyak 15 tenaga penjamah makanan dengan menggunakan total sampling. Data diperoleh menggunakan wawancara dan angket. Analisis statistika menggunakan ujichi-square. Hasil penelitian karakteristik petugas penjamah makanan didapatkan usia $\geq 30$ tahun sebanyak 86,7\%. Pendidikan penjamah makanan sebanyak 73,3\% SMU. Masa kerja penjamah makanan $\geq$ 10 tahun sebanyak 8 (53,3\%). Pengetahuan penjamah makanan, 53,3\% mempunyai pengetahuan baik, 66,7\% mempunyai sikap positif, pelaksanaan pengelolaan makanan di Instalasi Gizi RSUD Cideres tahun 2014 yaitu $73,3 \%$ sesuai standar, terdapat hubungan antara pengetahuan dengan praktek pelaksanaan pengelolaan makanan $p$ value 0,026 dan terdapat hubungan antara sikap dengan praktek pelaksanaan pengelolaan makanan di Instalasi Gizi RSUD Cideres Kabupaten Majalengka Tahun 2014, p value 0,004.
\end{abstract}

Kata kunci : Pengetahuan, Sikap, Pengelolaan makanan.

\begin{abstract}
Implementation of quality food in the hospital can not be separated from the power handlers, handlers power is a power that touches food and directly involved in preparing, processing, transporting and serving food. Based on interviews with 10 employees say that $65 \%$ lack of understanding about the operation of the food is good and right. The purpose of this study was to determine the relationship of knowledge and attitude of personnel management practices of food handlers in food in hospitals Nutrition Installation Cideres Majalengka 2014. This type of research is descriptive correlative study using cross- sectional approach (cross-sectional). The total sample of 15 workers total food handlers by using sampling. Data obtained using interviews and questionnaires and then analyzed statistically using the chi-square test. The results of the study characteristics of the officer seen food handlers aged $\geq 30$ years as much as $86.7 \%$. Education of food handlers as much as $73.3 \%$ of high school. Food handlers working life $\geq 10$ years as many as $8(53.3 \%)$. Knowledge of food handlers, $53.3 \%$ had good knowledge, $66.7 \%$ had a positive attitude, food management implementation in hospitals Nutrition Installation Cideres 2014 is $73.3 \%$ according to the standard, there is a relationship between knowledge management practice implementation of food $\mathrm{p}$ value 0.026 and there is a relationship between attitudes to food management practices implementation in hospitals Nutrition Installation Cideres Majalengka 2014, p value 0.004 .
\end{abstract}

Keywords : Knowledge, Attitudes, Management of food.

\footnotetext{
* Staf Pengajar Program Studi S1 Keperawatan STIKes Cirebon

** Alumni PSKM STIKes Cirebon Lulus Tahun 2014
} 


\section{PENDAHULUAN}

Memasuki era globalisasi yang ditandai dengan persaingan dalam berbagai aspek, diperlukan Sumber Daya Manusia (SDM) yang berkualitas tinggi agar mampu bersaing dengan negara lain. Kesehatan dan gizi merupakan faktor penting karena secara langsung berpengaruh terhadap kualitas SDM di suatu negara, yang digambarkan melalui pertumbuhan ekonomi, usia harapan hidup, dan tingkat pendidikan. Tenaga SDM yang berkualitas tinggi hanya dapat dicapai oleh tingkat kesehatan dan status gizi yang baik. Untuk itu diperlukan upaya perbaikan gizi yang bertujuan untuk meningkatkan status gizi masyarakat melalui upaya perbaikan gizi di dalam keluarga dan pelayanan gizi pada individu yang karena kondisi kesehatannya harus dirawat di sarana pelayanan kesehatan misalnya rumah sakit. ${ }^{1}$

Salah satu unit yang penting di rumah sakit dalam melayani kebutuhan pasien adalah Instalasi Gizi. Saat ini pelayanan gizi mulai dijadikan tolok ukur mutu pelayanan di rumah sakit. Terciptanya sistem pelayanan gizi yang bermutu di rumah sakit dengan memperhatikan berbagai aspek gizi dan penyakit, serta merupakan bagian dari pelayanan kesehatan secara menyeluruh, untuk meningkatkan dan mengembangkan mutu pelayanan gizi di rumah sakit. ${ }^{1}$

Pelayanan gizi di rumah sakit bertugas sebagai penyelenggara makanan yaitu suatu rangkaian kegiatan mulai dari perencanaan menu sampai dengan pendistribusian makanan kepada pasien, termasuk pencatatan, pelaporan, dan evaluasi dalam rangka pencapaian status kesehatan yang optimal melalui pemberian diet yang tepat. ${ }^{1}$

Penyelenggaraan makanan bermutu di rumah sakit tidak terlepas dari tenaga penjamah, tenaga penjamah adalah seorang tenaga yang menjamah makanan dan terlibat langsung dalam menyiapkan, mengolah, mengangkut maupun menyajikan makanan. Faktor kebersihan penjamah atau petugas makanan dalam istilah populernya disebut hygiene perorangan merupakan prosedur menjaga kebersihan dalam pengelolaan makanan yang aman dan sehat. ${ }^{1}$ Prosedur menjaga kebersihan merupakan perilaku bersih untuk mencegah kontaminasi pada makanan yang ditangani. Prosedur yang penting bagi pekerja pengolah makanan adalah pencucian tangan, kebersihan dan kesehatan diri. Statistik penyakit bawaan makanan yang ada di berbagai Negara industri saat ini menunjukan bahwa $60 \%$ dari kasus yang ada disebabkan oleh buruknya teknik pengolahan makanan serta terjadi kontaminasi pada saat disajikan di Tempat Pengelolaan Makanan (TPM). ${ }^{2}$

Penelitian ini bertujuan untuk mengetahui hubungan pengetahuan dan sikappetugas penjamah makanan dengan praktek pengelolaan makanan di Instalasi Gizi RSUD Cideres Kabupaten Majalengka bulan Maret 2014.

\section{METODE PENELITIAN}

Rancangan penelitian yang digunakan adalah explanatory research, menggunakan metode survey dengan pendekatan cross sectional. Desain penelitian ini dipilih untuk menilai hubungan variable independen terhadap variable dependen.Populasi dan sampel dalam penelitian ini adalah petugas penjamah makanan di Instalasi Gizi RSUD Cideres KabupatenMajalengka.Pengambilan sampel secara Total Sampling yaitu sebanyak 15 orang.

Pada penelitian ini yang menjadi variable independen adalah pengetahuan dansikap, sedangkan praktek pengelolaan makanan merupakan variable dependen.Dalam penelitian ini untuk variabel pengetahuan dan sikap, data diperoleh dengan menggunakan kuesioner. Sebelum pengisian kuesioner dilakukan persetujuan menjadi responden, kemudian kuesioner yang telah disusun diberikan kepada responden, dan responden dipersilahkan mengisi angket yang tersedia. 
Untuk variabel praktek pengelolaan makanan, pengumpulan data dilakukan dengan teknik observasi, dimana item terdiri dari dilaksanakan dan tidak dilaksanakan. Bila dilaksanakan mendapat skor 1 dan tidak dilaksanakan mendapat skor 0 .

Analisisunivariatdilakukanuntuk menyajikan distribusi frekuensi dari masing-masing variable. Sedangkananalisisbivariatdilakukanuntuk mengetahui adanya hubungan atau korelasi antara variabel independen dengan variabel dependen. Analisa ini menggunakan uji statistik chi-squaredengan metode koreksi Fisher probability exact test hal ini disebabkansampel yang digunakan terlalu kecil $(\mathrm{n}<20)$ serta nilai ekspektasi $<5$. $^{3}$

\section{HASIL PENELITIAN}

\section{Karakteristik responden}

Berdasarkan tabel dapat dilihat bahwa usia penjamah sebagian besar berusia $\geq 30$ tahun yaitu sebanyak $86,7 \%$. Pendidikan penjamah sebanyak $73,3 \%$ adalah SMU.Masa kerja penjamah makanan yang $\geq 10$ tahun sebanyak $8(53,3 \%)$.

\section{Pengetahuan Penjamah Makanan}

Berdasarkan gambaran pengetahuan penjamah makanan tentang pengelolaan makanan di Instalasi Gizi RSUD Cideres tahun 2014 bahwa sebanyak 53,3\% responden mempunyai pengetahuan baik.

Tabel 1. Pengetahuan Responden TentangPengelolaan Makanan

\begin{tabular}{lcc}
\hline \multicolumn{1}{c}{ Pengetahuan } & $\mathrm{f}$ & $\%$ \\
\hline Kurang Baik & 7 & 46,7 \\
Baik & 8 & 53,3 \\
\hline Jumlah & 15 & 100 \\
\hline
\end{tabular}

\section{Sikap Penjamah Makanan}

Tabel 2. SikapPenjamah Makanan Terhadap PraktekPengelolaan Makanan

\begin{tabular}{|c|c|c|}
\hline Sikap & f & $\%$ \\
\hline Negatif & 5 & 33,3 \\
\hline Positif & 10 & 66,7 \\
\hline Jumlah & 15 & 100 \\
\hline
\end{tabular}

Berdasarkan gambaran sikap penjamah makanan terhadap praktek pengelolaan makanan di Instalasi Gizi RSUD Cideres tahun 2014 menunjukkan bahwa 66,7\% responden mempunyai sikap positif.

\section{Praktek Pelaksanaan Pengelolaan Makanan}

Berdasarkan praktek pengelolaan oleh penjamah makanan di Instalasi Gizi RSUD Cideres tahun 2014 sebanyak 73,3\% responden melakukan praktek sesuai standar. 
Tabel 3. Praktek Pengelolaan MakananOleh Penjamah Makanan

\begin{tabular}{lll}
\hline \multicolumn{1}{c}{ Pelaksanaan Pengelolaan Makanan } & $\mathrm{f}$ & $\%$ \\
\hline Tidak sesuai standar & 4 & 26,7 \\
Sesuai standar & 11 & 73,3 \\
& & 100 \\
\hline Jumlah & 15 & \\
\hline
\end{tabular}

\section{Hubungan Pengetahuan dengan Praktek Pengelolaan Makanan}

Hasil analisis hubungan pengetahuan dengan praktek pengelolaan makanan diperoleh bahwa responden yang berada pada tingkat pengetahuan kurang hanya $42,9 \%$ yang memiliki praktek pengelolaan makanan sesuai standar, sedangkan responden yang memiliki tingkat pengetahuan baik seluruhnya atau $100 \%$ memiliki praktek pengelolaan makanan sesuai standar.

Tabel 4. Hubungan Antara Pengetahuandengan Praktek Pengelolaan Makanan

\begin{tabular}{|c|c|c|c|c|c|c|c|}
\hline \multirow{3}{*}{$\begin{array}{l}\text { Tingkat } \\
\text { Pengetahuan }\end{array}$} & \multicolumn{4}{|c|}{ Praktek Pengelolaan makanan } & \multirow{2}{*}{\multicolumn{2}{|c|}{ Jumlah }} & \multirow{3}{*}{$\mathrm{P}$ Value } \\
\hline & \multicolumn{2}{|c|}{$\begin{array}{l}\text { Tidak } \\
\text { Standar }\end{array}$} & \multicolumn{2}{|c|}{ Sesuai standar } & & & \\
\hline & $\mathrm{n}$ & $\%$ & $\mathrm{n}$ & $\%$ & $\mathrm{n}$ & $\%$ & \\
\hline Kurang & 4 & 57,1 & 3 & 42,9 & 7 & 100 & \\
\hline Baik & 0 & 0 & 8 & 100 & 8 & 100 & 0,026 \\
\hline Jumlah & 4 & 26,7 & 11 & 73,3 & 15 & 100 & \\
\hline
\end{tabular}

\section{Hubungan Sikap dengan Praktek Pengelolaan Makanan}

Hasil analisis hubungan sikap dengan praktek pengelolaan makanan diperoleh bahwa responden yang memiliki sikap positif, $100 \%$ melakukan praktek pengelolaan makanan sesuai standar.

Tabel 5. Hubungan Antara Sikapdengan Praktek Pengelolaan Makanan

\begin{tabular}{|c|c|c|c|c|c|c|c|}
\hline \multirow{3}{*}{ Sikap } & \multicolumn{4}{|c|}{ Praktek Pengelolaan makanan } & \multirow{2}{*}{\multicolumn{2}{|c|}{ Jumlah }} & \multirow{3}{*}{$\mathrm{P}$ Value } \\
\hline & \multicolumn{2}{|c|}{$\begin{array}{l}\text { Tidak } \\
\text { Standar }\end{array}$} & \multicolumn{2}{|c|}{ Sesuai standar } & & & \\
\hline & $\mathrm{n}$ & $\%$ & $\mathrm{n}$ & $\%$ & $\mathrm{n}$ & $\%$ & \\
\hline Negatif & 4 & 80 & 1 & 20 & 5 & 100 & \\
\hline Positif & 0 & 0 & 10 & 100 & 10 & 100 & 0,004 \\
\hline Jumlah & 4 & 26,7 & 11 & 73,3 & 15 & 100 & \\
\hline
\end{tabular}

\section{PEMBAHASAN}

\section{Pengetahuan Penjamah Makanan}

Berdasarkan hasil penelitian tentang pengetahuan penjamah makanan tentang pengelolaan makanan di Instalasi Gizi RSUD Cideres tahun 2014 ditemukan sebagian besar responden mempunyai pengetahuan baik

Hal tersebut berkaitan dengan tingkat penjamah makanan yang padaumumnyaberpendidikanmenengah bahkan sebagian sedang melanjutkan jenjang 
pendidikannya ke Strata S1. Tingkat pengetahuan seseorang dapat mempengaruhi perilaku dan akan berdampak terhadap pelaksanaan pengelolaan makanan. Sesuai penelitian Meikawati bahwa pengetahuan tenaga pengolah makanan di Unit Instalasi Gizi RSJ Dr Amino Gondohutomo Semarang sebagian besar berkatagori baik $50 \%{ }^{4}$

Selainituresponden sering mendapat informasi tentang pengelolaan makananbaik melalui pelatihan di rumah sakit maupun luar rumah sakit (mengikuti seminar-seminar, pelatihan) selain itu faktor yang mempengaruhi pengetahuan responden diantaranya pengalaman dan umur yang mempengaruhi perkembangan intelektual serta aspek fisiologis yang mana menentukan dalam mendapatkan pengetahuan.

Sesuai penelitian Marsaulina tahun 2004 menyatakan pengalaman kerja 1 tahun ke atas proporsi pengetahuan ke arah baik makin meningkat terlebih lagi pada pengalaman kerja diatas 2 tahun. ${ }^{5}$

Berdasarkan uraian diatas pengetahuan responden sebagian baik yaitu 53,3\% tetapi masih ada $46,7 \%$ mempunyai pengetahuan kurang sehingga perlu ditingkatkan pelatihan terutama yang berkaitan dengan pengelolaan makanan.

\section{Sikap Penjamah Makanan}

Berdasarkan hasil penelitian sebagian besar responden mempunyai sikap positif terhadap pengelolaan makanan hal ini berkaitan dengan pengalaman responden dimana adanya pengalaman dengan suatu obyek psikologis, seseorang cenderung membentuk sikap positif terhadap obyek tersebut.Disamping itu orang lain disekitar individu merupakan salah satu diantara komponen sosial yang ikut mempengaruhi sikap individu salah satunya petugas kesehatan, dari pimpinan dari instalasi gizi RSUD Cideres yang selalu melakukan pengawasan dan bimbingan terhadap penjamah makanan. ${ }^{6}$ Penelitian ini sejalan dengan penelitian Zulaikhah tahun 2009 bahwa sikap tentang responden yang mendukung terhadap sanitasi makanan $63,6 \% .^{7}$

Selain itu umur mempengaruhi pembentukan sikap dan perilaku seseorang. Semakin bertambahnya umur diharapkan seseorang bertambah pula kedewasaannya, makin mantap pengendalian emosinya dan makin tepat segala tindakannya.

Berdasarkan uraian diatas masih terdapat 33,3\% mempunyai sikap negative terhadap pengelolaan makanan di Instalasi Gizi RSUD Cideres sehingga perlu meningkatkan sikap menjadi positif salah satunya unsur pimpinan lebih meningkatkan motivasi dan bimbingan terhadap petugas penjamah makanan sehingga terbentuk interaksi sosial. Dalam interaksi sosial, terjadi hubungan saling mempengaruhi diantara individu yang satu dengan yang lain, terjadi hubungan timbal balik yang turut mempengaruhi pola perilaku masing-masing individu. Lebih lanjut, interaksi sosial itu meliputi hubungan antar individu dengan lingkungan fisik maupun lingkungan psikologis di sekelilingnya.Dalam interaksi sosialnya, individu beraksi membentuk pola sikap tertentu terhadap berbagai objek psikologis yang dihadapinya. ${ }^{6}$

\section{Praktek Pelaksanaan Pengelolaan Makanan}

Berdasarkan hasil penelitian tentang praktek pengelolaan oleh penjamah makanan di Instalasi Gizi RSUD Cideres tahun 2014 sebagian besar responden melakukannya sesuai standar. Hal tersebut berkaitan dengan masa kerja dimana 50\% responden sudah bekerja lebih dari 10 tahun dengan masa kerja lama seseorang semakin terbiasa melaksanakan pengelolaan makanan sesuai standar. Sesuai pendapat Widiastuti lama bekerja akan mempengaruhi keterampilan dalam melaksanakan tugas. Semakin lama bekerja maka keterampilan akan semakin meningkat. ${ }^{8}$ 
Selain itu umur seseorang mempengaruhi pelaksanaan pengelolaan makanan, semakin bertambahnya umur diharapkan seseorang bertambah pula kedewasaannya, makin mantap pengendalian emosinya dan makin tepat segala tindakannya. ${ }^{9}$ Disamping umur juga factor pendidikan penjamah makananberpendidikanmenengah bahkan sebagian sedang melanjutkan jenjang pendidikannya ke Strata S1.Dengan tingkat pendidikan mempunyai pengetahuan yang cukup sehingga tingkat pengetahuan seseorang dapat mempengaruhi perilaku yang akan berdampak terhadap pelaksanaan pengelolaan makanan.Hal ini didukung oleh pendapat Kuncoroningrat yang dikutip Nursalam dan Siti Pariani bahwa makin tinggi pendidikan seseorang, makin mudah menerima informasi sehingga semakin banyak pula pengetahuan yang dimiliki akan berdapak terhadap tindakan seseorang. ${ }^{10}$

Berdasarkan uraian diatas masih terdapat pelaksanaan yang tidak sesuai standar sebesar $26,7 \%$ sehingga perlu meningkatkan prosedur tetap tentang pengelolaan makanan di Instalasi Gizi RSUD Cideres selain itu untuk meningkatkan pengtahuan dan kemampuan perlu adanya pelatihan yang menunjang terhadap pengelolaan makanan.

\section{Hubungan Pengetahuan dengan Praktek Pengelolaan Makanan}

Hasil analisis statistik dengan menggunakan uji chi-square diperoleh p value0,026yang menunjukkan kurang dari 0,05, artinya terdapat hubungan yang bermakna antara pengetahuan responden dengan praktek pengelolaan makanandi Instalasi Gizi RSUD Cideres Kabupaten Majalengka Tahun 2014. Hal tersebut berkaitan dengan pengetahuan petugas penjamah yang baik, hasil penelitianpelaksanaan pengeloaanmakananyang sesuai standar ditemukan dengan tingkat pengetahuan baik100\% dibandingkan petugas penjamah makanan dengan tingkat pengetahuan kurang $42,9 \%$.

Sesuai hasil penelitian Meikawati terdapat hubungan antara pengetahuan dengan praktek hygiene dan sanitasi makanan di Unit Instalasi Gizi RSJ Dr Amino Gondohutomo Semarang 2008 dengan $\mathrm{p}$ value $0,003 .^{4}$

Pengetahuanadalahhasil dari tahu,dan ini terjadi setelah orang melakukan penginderaan terhadap suatu obyek. Penginderaan terjadi melalui panca indera manusia, yaitu penglihatan, pendengaran, penciuman,rasa, dan raba.

Sebagian besar pengetahuan manusia diperoleh melalui mata dan telinga. ${ }^{5}$ Pengetahuan merupakan domain yang sangat penting untuk terbentuknya tindakan seseorang, dari pengalaman dan penelitian terbukti bahwa perilaku yang didasari oleh pengetahuan akan berpengaruh baik dari pada perilaku yang tidak didasari oleh pengetahuan. Hal ini berdampak terhadap pengelolaan makanan oleh petugas penjamah makanan.

Walaupun pelaksanaan pengelolaan yang sesuai standar yang baik terdapat $73,3 \%$ tetapi masih ada $26,7 \%$ yang tidak sesuai standar sehingga diperlukan pelatihan baik internal maupun eksternal tentang penatalaksanaan pengelolaan makanandan sosialisasi tentang protap-protap yang berkaitan dengan pelaksanaan pengelolaan makanan untuk menambah pengetahuan atau mengingatkan kembali.

\section{Hubungan Sikap dengan Praktek Pengelolaan Makanan}

Hasil analisis statistik dengan menggunakan uji chi-square diperoleh p value0,004yang menunjukkan kurang dari 0,05 , artinya terdapat hubungan yang bermakna antara sikap responden dengan praktek pengelolaan makanandi Instalasi Gizi RSUD Cideres Kabupaten Majalengka Tahun 2014.

Hal tersebut berkaitan dengan pembentukan sikap yang disebabkan oleh pengalaman responden dimana adanya pengalaman dengan suatu obyek psikologis, seseorang cenderung membentuk sikap positif terhadap obyek tersebut.Disamping itu orang lain disekitar individu 
merupakan salah satu diantara komponen sosial yang ikut mempengaruhi sikap individu salah satunya petugas kesehatan, dari pimpinan dari instalasi gizi RSUD Cideres yang selalu melakukan pengawasan dan bimbingan terhadap penjamah makanan. ${ }^{6}$ Dengan pengalaman serta pengaruh dari unsur pimpinan di Instalasi gizi akan membentuk sikap positif akan berdampak terhadap pengelolaan makanan sesuai hasil penelitian tentang praktek pengelolaan makanan diperoleh sebanyak $20 \%$ sikap negatif dengan praktek pengelolaan makanan sesuai standar, sedangkan diantara sikap positif ada $100 \%$ dengan praktek pengelolaan makanan sesuai standar.

Sesuai hasil penelitian Meikawati terdapat hubungan antara sikap dengan praktek hygiene dan sanitasi makanan di Unit Instalasi Gizi RSJ Dr Amino Gondohutomo Semarang 2008 dengan $p$ value $0,017 .^{4}$

\section{SIMPULAN}

Ada hubungan yang bermakna antara pengetahuan dan sikap responden dengan praktek pengelolaan makanandi Instalasi Gizi RSUD CideresKabupaten Majalengka bulan Maret 2014

\section{SARAN}

Berdasarkan hasil penelitian disarankan kepada Instalasi Gizi RSUD Cideres Kabupaten Majalengka Perlu adanya dukungan dari pihak RS untuk mengikuti seminar, pelatihan pengelolaan makanan dan peningkatan strata pendidikan untuk pengembangan sumber daya manusia.

\section{DAFTAR PUSTAKA}

1. Kementrian Kesehatan RI, Buku pedoman pelayanan gizi rumah sakit,Dirjen Bina Kesehatan Masyarakat:Jakarta;2013.

2. Cahyaningsih, Kushadiwijaya, Tholib. Hubungan higiene sanitasi dan perilaku penjamah makanan dengan kualitas bakteriologis peralatan makan di warung makan. Berita Kedokteran Masyarakat Vol. 25, No. 4, Desember 2009 Balai Teknologi Kesehatan Lingkungan, Yogyakarta Bagian Ilmu Kesehatan Masyarakat, FK UGM, Yogyakarta Bagian Mikrobiologi:FK UGM Yogyakarta;2009.

3. Sugiyono, Statistika dalam penelitian. Bandung: CV Alfabeta;2007

4. Wulandari Meikawati, Rahayu Astuti. Hubungan pengetahuan dan sikap petugas penjamah makanan denganpraktek higiene dan sanitasi makanan di Unit Gizi RSJD Dr. Amino Gondohutomo Semarang Tahun 2010:Fakultas Kesehatan Masyarakat Universitas Muhammadiyas Semarang;2010.

5. Marsaulina,Irnawati. Study Tentang Pengetahuan Perilaku Dan Kebersihan Penjamah Makanan Pada Tempat Umum Pariwisata Di DKI Jakarta (TMII, TIJA, TMR):Fakultas Kesehatan Masyarakat Universitas Sumatera Utara;2004.

6. Azwar, S. Sikap manusia.Yogyakarta :Pustaka Pelajar;2003.

7. Zulaikhah. Faktor Perilaku yang Berhubungan dengan Kontaminan Bakteri Staphylococcus aureus pada Makanan Siap Saji.Vol. 1, No. 2, Juli-Desember 2009

8. Widiastuti.A. Faktor-faktor yang Berhubungan dengan Partisipasi Kader dalam Kegiatan Posyandu di Kelurahan Grobogan Tahun 2006:Fakultas Kesehatan Masyrakat Univeresitas Negeri Semarang. Semarang ;2007.

9. Yosvitra. Pengetahuan dan perilaku higiene tenaga pengolah makanan di Instalasi Gizi Rumah Sakit Umum Daerah Dr.Kanujoso Djatiwibowo Balikpapan:Program Studi Ilmu Gizi Fakultas Kedokteran Universitas Diponegoro Semarang;2011. 
10. Nursalam.Siti Pariani. Pendekatan Praktis Metodologi Riset Keperawatan. Jakarta: CV. Sagung setyo;2001

11. Notoatmojo S, Pengantar pendidikan kesehatan dan ilmu perilaku. Yogyakarta :Andi Offset;2003. 